\title{
PENYELEWANGAN DANA DALAM DUNIA PENDIDIKAN
}

\author{
Yusfiriadi $^{1}$, Wahyu Bagja Sulfemi ${ }^{2}$ \\ STKIP Muhammadiyah Bogor \\ surel: yoes_fitriadi@yahoo.com ${ }^{1}$.wahyubagja@gmail.com ${ }^{2}$
}

\begin{abstract}
Abstrak : Penelitian ini merupakan penelitian mengenai penyelewangan dana dalam dunia pendidikan dengan metode yang digunakan adalah metode studi pustaka. tulisan ini adalah bahwa penyelewangan dana atau dimasyarakat lebih dikenal dengan sebutan korupsi. Korupsi merupakan penyakit sosial dan moral. Dikatakan sebagai penyakit sosial disebabkan berimplikasi pada tatanan kehidupan secara holistik. Tindak korupsi tersebut akan merugikan orang banyak dan secara cepat akan menular kepada orang lain. Dikatakan sebagai penyakit moral disebabkan mengambil yang bukan haknya merupan tindakan keji secara etika. Ketika penyakit tersebut sudah sedemikian rupa kritis, tentunya sebagai tanggung jawab moral seorang dan komunitas anak bangsa yang mendambakan sebuah tatanan masyarakat yang adil dan beradab harus merasa resah. Sebagai wujud keresahan itu, penulis tuangkan dalam sebuah deskripsi sederhan dengan harapan akan dapat memperkaya khazanah intelektualitas khususnya bagi penulis sendiri. Lebih jauh penulis berharap tulisan ini bisa dipublikasikan lewat media apapun sebagai sebuah informasi alternatif solusi penanganan penyakit korupsi khususnya di sekolah.
\end{abstract}

\section{Kata Kunci : Penyelewengan, dana, pendidikan}

\begin{abstract}
This research is a study of fund fraud in the world of education with the method used is the literature study method. this paper is that the diversion of funds or in the community is better known as corruption. Corruption is a social and moral disease. It is said to be a social disease because it has implications for the life order holistically. Corruption will harm many people and will quickly spread to others. It is said to be a moral illness due to taking what is not his right to take ethically abominable actions. When the disease is in such a critical way, of course, as a moral responsibility, a person and community of children who long for a just and civilized society must feel anxious. As a manifestation of that anxiety, the author poured in a simple description in the hope that it would be able to enrich intellectual property, especially for the writer himself. Furthermore, the author hopes that this article can be published through any media as an alternative information solution for handling corruption, especially in schools.
\end{abstract}

Keywords: fraud, funds, education

\section{PENDAHULUAN}

Kurang lebih selama tiga puluh dua tahun bangsa Indonesia berada dalam krisis multidimensi. Krisis yang terjadi tidak hanya pada bidang eko-nomi dan moneter melainkan krisis moral dan krisis kepercayaan rakyat terhadap kinerja para penyelenggara pemerintahan. Krisis tersebut diantara-nya berawal dari ketidakmerataan pembangunan. Hal tersebut bisa dibukti-kan dengan kesenjangan pembangunan antara di pusat (Jakarta) dan di Pu-lau Jawa dengan wilayah-wilayah lain di Indonesia. Selain itu, terlihat pula fenomena yang cukup paradok, yaitu di sisi lain terlihat jelas gedung-gedung megah pencakar langit di jantung kota, di sisi lain juga bertebaran para pengemis dan gelandangan pada tempat yang sama.

Puncak akumulasi kondisi tersebut terjadi pada tahun 1998, yaitu mosi ketidakpercayaan rakyat Indonesia diwujudkan dalam bentuk kerusuhan dan penjarahan serta tindak kekerasan horizontal yang terjadi di kota Jakarta dan beberapa kota lain di Indonesia. 
Keadaan tersebut menyebabkan elemen-elemen muda terutama mahasiswa dan tokohtokoh yang resah atas masa depan bangsa ini mengungkap kondisi status quo rezim Orde Baru yang terindikasi penguasa korup yang menjadi penyebab munculnya krisis di atas.

Semenjak itulah istilah korupsi akrab dan bersahabat di telinga rakyat Indonesia, yang tadinya cukup ditabukan dengan istilah tersebut, yang kemudian digandengan dengan kata Kolusi dan Nepotisme. Tiga kata itulah yang kemudian penulis secara praksis menganggap setali tiga uang, artinya sulit dipisahkan pada tataran praktis.

Penyelewangan dana atau dimasyarakat lebig dikenal dengan Korupsi. Korupsi adalah penyakit dan kejahatan atas rakyat, penyakit dan kejahatan atas masyarakat, serta penyakit dan kejahatan atas negara secara keseluruhan. Sementara ini, korupsi baru dipahami sebagai penyakit dan kejahatan atas negara. Maka, pasalnya selalu berbunyi bahwa mereka merugikan negara. Kenyataan bahwa mereka juga merugikan uang rakyat dan uang masyarakat belum ditampilkan. Kalau kenyataan ini mampu di-tampilkan dan disadari oleh rakyat dan masyarakat, maka, ada kemungkinan rakyat dan masyarakat akan merasa berhak dan bertindak menggebuk mereka secara beramai-ramai, seperti halnya menggebug dan menindak pencuri ayam dan motor sebagaimana banyak terjadi, sekiranya pengadilan membebaskan mereka. Kalau ini terjadi, maka tayangan kriminal di teilvisi akan ada variasi dan diperkaya berita dan gambar bagaimana para koruptor dan pejabat korup kelas kakap dikejar-kejar aparat bersama rakyat dan masyarakat sampai ketempat persembunyian ketika melawan petugas. Dengan demikian, tayangan kriminal di televisi tidak membosankan karena hanya diisi dengan adegan pengejaran dan penembakan atas penjahat kelas teri melulu. Ini sesungguhnya yang ditunggu-tunggu oleh rakyat dan masyarakat.

Dalam skala makro, korupsi di Indonesia menjadi perhatian dunia, tepatnya tanggal 20 Oktober 2003, Bank Dunia mengeluarkan laporan tentang masalah korupsi di Indonesia. Bank Dunia menyatakan dalam laporan tersebut bahwa Indonesia sesungguhnya tengah memperkuat kerangka akuntabilitasnya, tapi dampaknya masih terlalu kecil untuk memerangi korupsi yang telah meluas, buktinya hanya segelintir orang saja yang dipidana karena kejahat korupsi.

Korupsi sering kali didefinisikan sebagai penyalahgunaan jabatan untuk kepentingan pribadi. Definisi korupsi yang lebih lengkap yang juga mengandung unsur akibatnya pada hubungan-hubungan dalam masyarakat atau antara pemberi dan penerima suap adalah penyalahgunaan kekuasaan untuk kepentingan pribadi atau penyalahgunaan kepercayaan untuk kepentingan pribadi. Adapun penulis mendefinisikan korupsi dalam tataran praksis adalah cenderung lebih luas dengan menyamakan dengan perilaku kriminal dan perilaku yang buruk secara moral, termasuk pencurian dan penipuan. Walaupun begitu pada ujung yang lain beberapa orang tidak menganggap pembayaran tak resmi yang dilakukan dengan sukarela sebagai supa karena mereka memilih untuk melakukannya. Lebih konkret Syed Husein Alata (2001: 88) dalam bukunya yang berjudul Korupsi, Hakikat, Sebab dan Fungsinya yang diterbitkan oleh LP3ES menyatakan bahwa "...Korupsi dianggap sebagai pencurian yang dilakukan dengan menipu dalam situasi yang menghianati kepercayaan." Selajutnya ia juga mengatakan bahwa korupsi seringkali lebih tidak kentara dan sifatnya memaksa sehingga lebih tidak kentara daripada pencurian atau tidak kejahatan.

Untuk lebih konprehensif, maka Masdar F. Mas'udi (2004: 9) memberikan definisi korupsi dalam perspektif budaya dan syari'at Islam, dia menyatakan bahwa praktik money politics merupakan salah satu bentuk suap atau dalam Islam dikenal dengan istilah risywah, yakni "pemberian untuk mempengaruhi keputusan pihak penerima agar menguntungkan pemberi secara melawan hukum." Ia menyebut suap sebagai perbuatan menukarkan Allah dengan sesuatu yang bersifat materi, dengan demikian merupakan tindakan yang dikutuk, tidak hanya oleh manusia juga oleh Allah. 
Sesuai dengan uraian di atas, maka tindak penyakit dan kejahatan korupsi bisa terjadi di mana saja, para pejabat legislatif, pemerintah (Penyelenggara Negara) tingkat pusat hingga daerah, rumah sakit, para penegak hukum, sekolah, dan lain-lain.

\section{METODOLOGI PENELITIAN}

Metode yang digunakan dalam makalah ini adalah metode deskriptif analitis dengan pendekatan kualitatif menggunakan studi dokumentasi dan studi kepustakaan. Sugiyono (2006 11) menerangkan bahwa penelitian deskriptif adalah penelitian yang dilakukan untuk mengetahui nilai variable mandiri, baik satu variabel atau lebih (independen) tanpa membuat perbandingan, atau menghubungkan antara variabel satu dengan variable yang lain. James $\mathrm{H}$. McMillan dan Sally Schumacher (2001: 451) mengemukakan bahwa studi dokumentasi merupakan strategi tidak langsung untuk memperoleh data kualitatif. Pencermatan terhadap dokumen merupakan manifestasi yang terukur dan menjelaskan pengalaman, pengetahuan, kegiatan, dan nilai-nilai seseorang atau lembaga. Tulisan ini membahas tentang penyelewangan dana dalam dunia pendidikan

\section{HASIL PENELITIAN DAN PEMBAHASAN}

Karena luasnya permasalahan korupsi seperti telah penulis uraikan pada poin B, maka penulis mencoba untuk menganalisis praktik korupsi yang terjadi pada institusi sekolah. Yang menarik bagi penulis mengapa penyakit korupsi di sekolah yang diangkat? selian kejahatkejahat korupsi yang ada pada tubuh legislatif, birokrasi Penyelenggara Pemerintahan, BUMN telah banyak yang mengungkap, baik melalui media cetak maupun elektronik. Selain itu juga, lembaga pendidikan dalam hal ini sekolah merupakan tempat di mana masa depan anak bangsa dipertaruhkan, sehingga bagaimana jadinya anak bangsa ke depan jika sejak dini di tempat mereka sudah terjangkit penyakit moral yang bernama korupsi, sehingga implikasinya adalah lembaga pendidikan yang berorientasi pada "memanusiakan manusia" dengan kata lain "berkeadilan dan berkeadaban" hanya akan menjadi sebuah pembenaran terhadap kebohongan pada tataran praktis di sekolah.

Sebagai telaah, tata pendidikan berkeadilan sosial adalah usaha membangun sistem pendidikan yang memberikan alternatif terhadap sistem pendidikan yang telah ada. Sistem pendidikan yang telah ada tergambar dalam dua persoalan besar pendidikan Indonesia. Pertama, Paradigma dan pendekatan pendidikan yang salah. Pada tataran ini dibuktikan dengan masih adanya pendekatan yang dilakukan, baik oleh penyelenggara pemerintahan ataupun rakyat dan masyarakat adalah dengan pendekatan perbedaan perlakuan terhadap sekolah-sekolah yang berstatus negeri, maupun yang berstatus swasta, sehingga subsidi pemerintah pun dalam hal ini seringkali berpihak kepada sekolah yang berstatus negeri, sedangkan sekolah yang berstatus swasta terkadang dianaktirikan. Kedua, masih adanya pengelolaan pendidikan dua atap. Artinya di Indonesia pengelolaan pendidikan pada tataran pelaksanaanya terdapat dua atap yang mengelola, yaitu Departemen Pendidikan Nasional (DEPDIKNAS) dan Departemen Agama (DEPAG). Hal itu berimplikasi pada susahnya menentukan standarisasi, pengawasan, penyamaan visi dan perlakuan baik perlakuan pemerintah, maupun masyarakat. Kalau kedua persoalan besar pendidikan itu tidak diselesaikan, baik nilai-nilai yang menjadi pembimbing tujuan pendidikan, maupun unsurunsur yang membangun isi pendidikan, akan sulit sekali untuk dicapai dan diselenggarakan. Walaupun bukan wilayah paper ini untuk membahas dua masalah pendidikan di atas, namun masalah tersebut akan menimbulkan berbagai macam efek pada tataran lembaga pendidikan (sekolah), termasuk dalam hal ini penyakit korupsi.

Perihal korupsi di sekolah, Darmaningtyas (1999) dalam Wahono (2001: 110) dalam memberikan sinyalemen bahwa sekolah kita mempunyai jumlah siswa dari Taman Kanakkanak (TK) hingga SMTA, per tahun rata-rata 37 juta. Ini merupakan pasar besar untuk 
perushaan-perusahaan swasta (penerbit buku pelajaran, alat-alat tullis, kain seragam, biro wisata, dan lain-lain). Selanjutnya dia juga mengatakan bahwa guru dalam lembaga sekolah juga ikut berbisnis, dengan menjadi rekanan perusahaan, tetapi juga dengan membisniskan kursi pendidikan melalui dana sumbangan pembangunan lengkap dengan tawar-menawarnya serta dengan jual beli nilai oleh sementara oknum guru, melalui les, maupun langsung di atas kertas garapan.

Berpijak dari narasi-narasi di atas, maka penulis menganalisis bentuk-bentuk korupsi di dunia pendidikan, khususnya sekolah di antaranya: Pertama Orang tua murid harus menyuap guru agar raport (laporan hasil belajar) anaknya dapat keluar. Laporan hasil Belajar yang sering dikenal dengan istilah raport, merupakan sesuatu yang ditunggu-tunggu dengan penuh harap cemas oleh setiap orang tua yang peduli terhadap anak-anaknya yang masih duduk di bangku sekolah, sehingga segala upaya pun dilaksanakan oleh orang tua demi keluarnya buku raport tersebut. Namun terkadang kondisi tersebut dimanfaatkan oleh seorang guru yang mempunyai penyakit sosial modernitas (Materialistik), yakni, dengan memungut bayaran untuk biaya keluarnya raport tersebut. Fenomena semacam ini tidak sedikit kita temukan di beberapa lembaga pendidikan terutama sekolah.

Kedua Berbagai macam iuran yang berlebihan. Biasanya sebuah sekolah sudah mencantumkan atau memaklumatkan iuran-iuran resmi dan iuran tidak resmi yang akan dikenakan kepada wali murid selama anaknya dalam proses pendidikan ketika rapat wali murid. Namun pada tataran implementasinya dengan berbagai retorika guru yang membuat ketakutan-ketakutan masa depan siswa, iuran-iuran tersebut menjadi membenghkak baik kuantitas bentuk iuiran maupun kualitas iuran yang harus dikeluarkan. Penulis mencatat beberapa di antara iuran yang dikenakan oleh sekolah atau seorang guru yang penulis anggap tidak proporsional bahkan penulis menganggap sebagai bentuk kejahatan sosial, yakni: Iuran Bangunan yang besarnya tidak sesuai dengan penyediaan sarana dan prasarana serta fasilitas yang se-layaknya, iuran peringatan hari-hari besar Nasional dan Keagamaan yang berlebihan dan cenderung memaksakan, Iuran Tunjangan Hari Raya bagi guru, Iuran perpisahan (bagi Kelas 6 SD dan Kelas 3 SLTP/SMTA) yang tidak bersifat edukatif, dan sebagainya.

Ketiga Sekolah menuntut bunga untuk uang gedung yang dicicil. Penulis menemukan sebuah fenomena yang cukup tidak memanusiakan pendidikan dan cenderung bernuansa bisnis dalam item ini, yakni tidak samanya jumlah keuangan yang dikeluarkan oleh wali murid dalam membayar uang bangunan (uang gedung) bagi yang dibayar secara kontan dengan yang cara pembayarannya dicicil.

Keempat uang masuk khusus Label sekolah Unggulan ternyata juga memberikan peluang sekolah tersebut untuk berprilaku diskrimatif dalam bidang keuangan bagi siswa yang akan memasuki sekolah tersebut. Hal ini menurut pandangan penulis sudah bukan rahasia umum lagi di mana bagi orang tua yang menginginkan putra/puterinya belajar di sekolah tersebut, padahal tidak memenuhi standar kualifikasi akan dengan mudah dapat tiket masuk, dengan konvensasi dikenakan keuangan yang cukup besar dibandingkan siswa yang secara normal memasuki lembaga pendidikan tersebut. Jika kasus ini tida segera di atasi, selain menciptakan Sumber Daya Manusia Pendidikan yang bermental korup, juga akan berakibat fatal bagi output sekolah tersebut.

Kelima pemotongan dan Pengambilan Dana Beasiswa. Bantuan-bantuan untuk siswa baik siswa yang berprestasi ataupun siswa yang tidak mampu sudah menjadi umum dikeluarkan oleh pemerintah ataupun lembaga/perorangan. Namun pada tataran realitas penulis menemukan sebuah kasus dana beasiswa tersebut tidak diketahui oleh siswa sendiri, sehingga akibatnya dana tersebut tidak sampai kepada siswa, bahkan yang sangat tragis dana bantuan pendidikan tersebut tidak sampai sama sekali kepada yang berhak menerimanya.

Keenam orang Tua harus membeli seragam sekolah dengan harga yang jauh dari harga pasar. "Siapa yang tak mengeluh, Kenapa sih harus ada seragam wajib di sekolah, kalau kami 
bisa memiliki pakaian sekolah dengan cara lain untuk mendapatkannya? pakaian itu pun sangat tak bisa diterima. Bayangkan uang seragam seharga Rp340.000,00 tapi anak saya diberi seragam dengan kualitas apa adanya. Lebih baik kami beli dipasar atau jahit sendiri." Keluhan di tersebut merupakan kondisi riil yang sering terjadi. Sekolah cenderung mengambil keuntungan yang cukup besar bekerja sama dengan sebuah perusahaan yang memproduksi pakaian. Padahal kalau seragam tersebut dan memang banyak di pasaran bisa dibeli sendiri, kemungkinan akan jauh lebih murah.

Ke tujuah orang tua harus membeli buku dan media belajar lain dengan harga yang ditinggikan. Keberadaan media belajar seperti buku dan semacamnya merupakan sesuatu yang tidak bisa dibantah, namun selain buku-buku yang zaman sekarang ini pada umumnya mempunyai harga yang cukup tinggi, juga orang tua dibebani kondisi kurikulum pendidikan yang dengan cepat mengalami perubahan-perubahan, sehingga secara otomatis paket-paket buku yang mahal-mahal itupun dengan mudah harus diganti. eban orang tua tidak cukup disitu, ternyata kondisi tersebut diperparah dengan ditinggikannya harga buku oleh sekolah/guru yang wajib dimiliki oleh setiap siswa. Adanya Lembar Kerja Siswa (LKS) yang akhir-akhir ini menjadi penghasilan sampingan sekolah/guru ikut serta memberikan kontribusi terhadap perilaku penyakit sosial di sekolah, di mana seluruh siswa diwajibkan membeli LKS secara rutin dengan harga yang tidak murah juga. Sehingga muncul keluhan orang tua : "Harusnya Ibu atau Pak Guru bisa mengerti bahwa tidak hanya dengan metode LKS anakanak bisa dipaksa untuk mengerti mata pelajarannya. Mungkin ada cara lain agar kami yang berpenghasilan pas-pasan ini bisa hidup juga"

Kedelapan guru honor dan Guru Kontrak menerima gaji tidak sesuai dengan waktu SK (Surat keputusan Kerja) dikeluarkan. Penulis akhir-akhir ini menemukan sebuah fenomen 'korupsi berantai' di sekolah. Korupsi tersebut melibatkan Dinas pendidikan dan Guru. Seorang guru bantu atau guru kontrak baru menerima Surat Keputusan pengangkatan pada Bulan September, padahal dalam surat itu tercatat dan baru diketahui oleh yang bersangkutan menjadi guru bantu/kontrak sejak bulan Maret. Sehingga implikasinya adalah bahwa gaji/honor dari bulan maret hingga bulan September diberikan secara rapel (sekaligus). Pertanyaannya adalah: Berapa jumlah guru bantu/kontrak yang diangkat di sebuah kabupaten dan berapa jumlah honor yang ditimbun pada sebuah bank dalam kurun waktu kurang lebih 6 bulan tersebut? bisa dibayangkan berapa bunga yang diperoleh per bulan oleh seorang atau institusi yang menimbun uang gaji tersebut!. Apapun pertanyaan bagi guru adalah: Dengan ketidaktahuan status sebagai guru Bantu/Kontrak selama waktu tersebut, bagaimana status honor/gaji yang dirapelkan tersebut? dan Upaya apa yang telah dilakukan guru/sekolah dalam menyikapi penimbunan uang tersebut?

Kesepuluh tenaga pendidikan Guru atau non-Guru dengan status Pegawai Negeri Sipil (PNS) senantiasa menerima gaji walaupun tidak masuk kerja. Tentu point ini bukan sebagai upaya mendiskriditkan tenaga pendidikan yang bertatus Pegawai Negeri Sipil (PNS), namun di lapangan penulis menemukan banyak kasus yang menunjang poin ini. Bagi pegawai swasta mereka harus hadir dan mengisi daftar hadir yang ketat setiap ada jadwal, sehingga gaji yang dikeluarkan pihak sekolah pun sesuai dengan kehadirannya. Tidak begitu halnya dengan tenaga pendidik yang berstatus PNS di sekolah, masuk atau tidak masuk kelas dia akan mendapatkan gaji tetap bulanan, sehingga kondisi ini tidak jarang mengakibatkan seorang tenaga pendidikan guru atau nonguru yang berstatus PNS banyak tidak masuk kerja karena mengurusi bisnisnya sendiri atau ngurusin yang lain. Yang penulis katakan pada poin ini tidak sedikit guru/non-guru disekolah yang memakan gaji buta selama dia berstatus PNS. Hal ini jelas-jelas selain merugikan uang negara juga mengorbankan profesi guru yang tidak bertanggung jawab terhadap masyarakat.

Kesebelas guru mengenakan sanksi dengan materi (uang). Penugasan juga Strategi Belajar Mengajar untuk mencapai sebuah tujuan instruksional, namun dalam pelaksanaannya 
terkadang ada siswa yang tidak bisa menyelesaikan tugas tersebut. Dalam kasus ini tidak jarang juga penulis menemukan kasus guru mengenakan sanksi kepada siswa yang tidak bisa menyelesaikan tugas dengan sanksi yang sama sekali tidak mengandung sisi edukatif, seorang guru mengenakan sanksi yang berbentuk materi (uang). Tentu hal ini selain jauh dari rasionalitas, juga akan menjadi preseden buruk, baik bagi guru itu sendiri maupun bagi siswa. Bagi guru tentu hal ini merupakan penyakit sosial yang akan mengakibatkan meterialistik, adapun bagi siswa, jelas uang merupakan senjata ampuh untuk menutupi segala macam tugas yang diberikan oleh guru, sedangkan profesi keguruan juga ikut serta ternodai.

Kedua belas her atau perbaikan nilai dengan konpensasi uang dari siswa. Dalam sebuah kelas terkadang ada saja siswa yang dalam menempuh ulangan/ujian/tes lainnya mendapatkan nilai yang tidak masuk ke dalam standar kelulusan, konsekuensi yang harus ditanggung oleh siswa di-antaranya memperbaiki nilai tersebut dengan cara mengulang atau dibebankan tugas edukatif tambahan. Namun di sini juga terkadang seorang guru menerapkan jurus jitunya untuk memperbaiki nilai seorang siswa secara instan, "dengan transaksi nilai" atau yang lebih populer dengan istilah "Jual beli nilai". Fenomena ini jelas akan mengakibatkan kepada pencitraan yang buruk, baik bagi institusi pendidikan tersebut, profesi keguruan atau guru itu sendiri.

Ketiga belas Uang Ujian akhir yang telah dimark-up. Ujian Akhir Sekolah (UAS) merupakan kegiatan akademik yang wajib diikuti oleh seluruh siswa, sebagai wahana evaluasi akhir untuk mengukur lulus atau tidaknya siswa dalam proses belajar selama satu jenjang pendidikan di sekolah. Namun tentu saja administrasi keuangan meru-pakan syarat mutlak yang harus dipenuhi oleh seorang siswa sebelum menempuh ujian tersebut. Ketika administrasi keuangan yang dibebankan kepada siswa tersebut normal-normal saja atau sesuai ketentuan yang ada, kemungkinan orang tua tidak akan merasa dirugikan, walau hal itu akan menguras tenaga dan energi untuk menutupinya terutama bagi keluarga yang kurang mampu. Sebuah penyakit moral juga mempunyai peluang untuk tumbuh subur dipoin ini. Hal itu dibuktikan dengan bebe-rapa sekolah yang memark-up biaya tersebut, sehingga masyarakatlah yang kembali menjadi korban atas tindakan ini. Sehingga, tidak sedikit orang tua yang mencabut anaknya dari sekolah disebabkan hal itu, kalau kondisi seperti terus dipertahankan maka, berapa anak bangsa yang tidak mampu mengikuti ujian dan menamatkannya dari sebuah sekolah yang menjadi impian seluruh orang tua?

Tentu kasus-kasus di atas mungkin bersifat kasuistik, artinya hanya terjadi di beberapa lembaga pendidikan, namun dengan segala keterbatasan dan kapasitas, itulah realitas yang mampu diamati dan dianalisis oleh penulis, walaupun sangat mungkin adanya berbagai macam kasus yang luput dari pengamatan penulis.

Penyakit sosial yang berbentuk "korupsi di sekolah" sudah sedemikian marak dipertontonkan oleh segenap insan pendidikan di sekolah. Bahkan, hal ini sudah merupakan penyakit kronis dan akut. Namun, tentu saja bukan berarti tidak ada obat yang ampuh untuk menyebuhkan penyakit tersebut walaupun sampai pada tahap amputasi dan dengan biaya yang cukup tinggi.

Penulis cukup menyadari bahwa pemberantasan korupsi dalam bentuk apapun dan di manapun termasuk di sekolah tidak akan mampu diberantas dalam waktu singkat dan dengan cara yang mudah. Namun, minimal kita harus mencari solusi konkret sebagai niat baik untuk melangkah melawan penyakit tersebut, sehingga walaupun target bersih korupsi tidak mudah terwujud, namun sebagai bentuk meminimalisasikan dan shock therapy saya pikir sudah merupakan langkah maju menuju bersih korupsi tersebut.

Dalam poin saran dan tindak lanjut ini, penulis akan lebih memberikan penekanan pada penanganan praktis dalam mengatasai permasalahan korupsi di sekolah, walaupun tidak akan menampilkan penanganan kasus per kasus. Terdapat beberapa strategi yang menurut penulis akan mampu dijalankan oleh lembaga sekolah untuk secara bertahap meminimalisisakan 
tindak kejahatan korupsi di sekolah. Keyakinan tersebut setelah mengamati tataran relitas sekolah yang ada di sekeliling penulis, walaupun mungkin secara tekstual solusi ini bukan sesuatu hal yang aneh, namun penulis akan lebih menyoroti sisi kontekstual yang teramat banyak sisi-sisi lain yang belum tersentuh.

Dewan Sekolah (School Council) yang digagas oleh Tim Nasional Reformasi Menuju Masyarakat Madani Kelompok Pendidikan dan Pengembangan SDM merupakan subsistem dari konsep Pendidikan Berbasis Masyarakat (PBM), yang muncul sebagai aplikasi konsep dari otonomi pendidikan. Hal ini kemudian oleh praktisi pendidikan kita diterjemahkan sebagai Komite Sekolah. Hal yang mampu penulis tangkap dengan keterbatasan kapasitas, wawasan dan pengamatan, secara ideal Komite Sekolah merupakan kepanjangan tangan dari masyarakat sebagai wujud pengawasan masyarakat dan rasa memiliki terhadap lembaga sekolah tersebut. Namun pada tataran realitas, Komite Sekolah yang sekarang dibentuk di masing-masing sekolah tak ubahnya seperti "Boneka Sekolah". Walaupun mungkin ungkapan ini terlalu didramatisir, namun kenyataannya tidak bisa dihindari. Hal itu secara nyata bisa dibuktikan dengan beberapa hal di antaranya adalah: Pertama, Komite Sekolah dibentuk oleh sekolah, sehingga lembaga itu diisi oleh orang-orang yang secara individual tidak lagi independen karena direkrut berdasarkan keinginan sekolah, yang pada akhirnya seluruh kinerja yang ditampilkan oleh Komite Sekolah tersebut merupakan sekenario sekolah. Padahal fungsi-fungsi Komite Sekolah justru sebagai "Media Control" terhadap lembaga. Kedua, Ketumpulan Kritis Komite Sekolah disebabkan oleh perekrutan personal Komite Sekolah yang syarat kepentingan, sehingga Komite Sekolah secara kelembagaan tidak berdaya untuk mengkritisi ketimpangan-ketimpangan yang terjadi di sekolah-sekolah termasuk ketidakberdayaan mengkritisi masalah praktik-praktik korupsi di sekolah. Ketiga, Komite Sekolah keberadaannya tidak dirasakan baik oleh masyarakat ataupun oleh sekolah itu sendiri. Kondisi ini selain disebabkan oleh perekrutan personal yang tergabung dalam Komite Sekolah itu terkesan tidak serius, juga memang respon masyarakat yang tidak begitu bagus terhadap keberadaan Komite Sekolah dan masyarakat cenderung apatis, dan terkesan menyerahkan segala macam permasalahan sekolah kepada sekolah itu sendiri. Sehingga, Komite Sekolah tidak tahu perkem-bangan sekolah. Masyarakat merasa kesulitan tatkala menginginkan sebuah fakta otentik mengenai hal-hal yang terjadi di sekolah.

Lembaga Pengawasan dan Pengendali Mutu Pendidikan Sekolah yang independen. Sebatas pengamatan penulis, hanya sebagian kecil lembaga pendidikan, terutama sekolah yang mempunyai Lembaga Pengendali Mutu. Lembaga ini justru banyak digunakan oleh lembaga-lembaga usaha yang berorientasi financial, seperti perusahaan konveksi, perusahaan elektronik, departemen store dan lain-lain. Di lembaga pendidikan yang justru harus mengedepankan mutu anak bangsa, jarang sekali ditemukan. Sehingga diharapkan dengan adanga lembaga ini atau lebih kepada fungsinya, segala macam perkembangan sekolah baik secara institusi maupun unsur-unsur yang ada di dalam sekolah akan mudah diketahui. Menurut hemat penulis, lembaga pengawasan dan pengendali mutu pendidikan di sekolah bisa direkrut orang-orang profesional atau unsur Komite Sekolah itu sendiri yang memungsikan dirinya ke arah itu.

Ironis sekali ketika kita menyaksikan fenomena seorang guru setiap saat "mengeksploitasi" siswa secara kognitif, sedangkan guru itu sendiri tidak tertarik terhadap pengayaan-pengayaan spiritual, inteletual, dan moral. Maka penulis menjadikan Kajian Rutin, entah itu bulanan, dua bulanan atau per triwulan merupakan salah satu solusi dari permasalahan penyakit moral yang bernama korupsi di sekolah. Dalam kajian rutin tersebut bisa dikaji masalah-masalah yang menyangkut spritual, moral guru, mempertegas visi dan misi sekolah, strategi belajar mengajar, bahkan mengungkap persoalan-persoalan yang terjadi dalam proses belajar-mengajar. Sehingga, selain jalinan shilaturrahmi antarguru dan elemenelemen yang ada di sekolah tersebut semakin erat, secara kebutuhan-kebutuhan intelektialis 
pun tersantuni, serta masalah-masalah yang terjadi di sekolah akan secara rutin diketahui oleh seluruh unsur-unsur yang ada disekolah tersebut, yang pada akhirnya setiap permasalahan akan segera di atasi.

Political will Pemerintah. Dalam poin ini, penulis akan lebih tepat dan bijak jika mengungkapkan saran-saran bagi kepanjangan pemerintah yang menangani masalah pendidikan di sekolah, yang dalam hal ini Dinas Pendidikan dan Pengajaran di Tingkat Kecamatan atau Kabupaten/Kota.

Menempatkan seorang Manajer Sekolah (Kepala Sekolah) yang sudah memahami betul baik secara psikologis dan karakter unsur-unsur yang terdapat di sekolah, maupun secara kultur yang ada di lingkungan masyarakat itu sendiri, tidak menempatkan orang baru yang harus memakan waktu lama dalam beradaptasi. Akan lebih berdampak baik ketika Kepala Sekolah tersebut bukan ditempatkan tetapi dipilih oleh sekolah itu sendiri, sehingga sesuai dengan kebutuhan unsur-unsur yang ada di sekolah.

Respon terhadap laporan-laporan pihak sekolah yang kemudian ditindaklanjuti dengan langkah konkret. Mengoptimalkan fungsi kontrol dan pengawasan serta pemberdayaan sekolah sesuai dengan gugus tugas yang sudah dipetakan oleh Dinas Pendidikan. Mengenai hal ini, sering penulis saksikan bahwa seorang Penilik, yang merupakan kepanjangan tangan Dinas Pendidikan dan Pengajaran yang mempunyai tugas Kontrol, pengawasan, dan pemberdayaan sekolah secara rutin, tidak optimal, yang terjadi kebanyakan adalah datang hanya untukl sekadar formalitas (setor muka ke sekolah), dan pulang dengan diberi amplop. Jika kondisi ini terus terpelihara maka, selain pencitraan baik secara personal maupun institusional (Dinas Pendidikan dan Pengajaran) kurang baik, juga akan menumbuhsuburkan budaya korupsi baik di sekolah ataupun di dinas itu sendiri.

\section{KESIMPULAN DAN SARAN}

\section{A. KESIMPULAN}

Kita telah memulai dari tulisan ini adalah bahwa korupsi merupakan penyakit sosial dan moral. Dikatakan sebagai penyakit sosial disebabkan berimplikasi pada tatanan kehidupan secara holistik. Tindak korupsi tersebut akan merugikan orang banyak dan secara cepat akan menular kepada orang lain. Dikatakan sebagai penyakit moral disebabkan mengambil yang bukan haknya merupan tindakan keji secara etika. Ketika penyakit tersebut sudah sedemikian rupa kritis, tentunya sebagai tanggung jawab moral seorang dan komunitas anak bangsa yang mendambakan sebuah tatanan masyarakat yang adil dan beradab harus merasa resah.

Sebagai wujud keresahan itu, penulis tuangkan dalam sebuah deskripsi sederhana, dengan harapan akan dapat memperkaya khazanah intelektualitas khususnya bagi penulis sendiri. Lebih jauh penulis berharap tulisan ini bisa dipublikasikan lewat media apapun sebagai sebuah informasi alternatif solusi penanganan penyakit korupsi khususnya di sekolah.

Akhirnya, dengan segala kerendahan hati penulis mohon maaf yang sebesar-besarnya atas segala kesalahan baik secara substansial maupun secara redaksional apabila dalam tulisan ini jauh dari kesempurnaan.

\section{B. SARAN}

1. Dewan Sekolah (School Council) harus lebih progresif jsebagai "Media Control" terhadap lembaga.

2. Lembaga Pengawasan dan Pengendali Mutu Pendidikan Sekolah yang independen harus mengedepankan mutu anak bangsa, jarang sekali ditemukan. Sehingga diharapkan dengan adanga lembaga ini atau lebih kepada fungsinya, segala macam perkembangan sekolah baik secara institusi maupun unsur-unsur yang ada di dalam sekolah akan mudah diketahui. 
3. Dinas Pendidikan dan Pengajaran di Tingkat Kecamatan atau Kabupaten/Kota. menangani masalah pendidikan di sekolah. Mengoptimalkan fungsi kontrol dan pengawasan serta pemberdayaan sekolah sesuai dengan gugus tugas yang sudah dipetakan oleh Dinas Pendidikan

4. Menempatkan seorang Manajer Sekolah (Kepala Sekolah) yang sudah memahami betul baik secara psikologis dan karakter unsur-unsur yang terdapat di sekolah, maupun secara kultur yang ada di lingkungan masyarakat itu sendiri. Mererespon terhadap laporanlaporan pihak sekolah yang kemudian ditindaklanjuti dengan langkah konkret.

\section{Daftar Pustaka}

Francis Wahono, 2001. Kapitalisme Pendidikan Antara Kompetisi dan Keadilan. Yogyakarta: Insist Press, Cindelaras, Pustaka Pelajar.

Majalah Tengah Bulanan Suara Muhammadiyah, 2004. Membuat Koruptor Menggigil, Yogyakarta: Pers Suara Muhammadiyah.

Mastuhu, 2004. Menata Ulang Pemikiran Sistem Pendidikan Nasional dalam Abad 21. Yogyakarta: Safira Insani Press, MSI UII.

Newsletter, 2004. Anti Korupsi Harus Jadi Agenda Utama Sebelum dan Sesudah Pemiu 2004, Jakarta: Kemitraan Bagi Pembaruan Tata Pemerintahan di Indonesia.

Ratih Hardjono dan StefanieTeggemann (editor), 2001. Kaum Miskin Bersuara, Jakarta: Kemitraan Bagi Pembaruan Tata Pemerintahan di Indonesia.

Tim Nasional Reformasi Menuju Masyarakat Madani Kelompok Pendidikan dan Pengembangan SDM, 1999. Platform Reformasi Pendidikan dan Pengembangan Sumber Daya Manusia. Jakarta: PT Logos Wacana Ilmu, Jakarta, 1999.Ratih Hardjono dan StefanieTeggemann (editor), 2001. Kaum Miskin Bersuara, Jakarta: Kemitraan Bagi Pembaruan Tata Pemerintahan di Indonesia,

Tim Nasional Reformasi Menuju Masyarakat Madani Kelompok Pendidikan dan Pengembangan SDM, Platform Reformasi Pendidikan dan Pengembangan Sumber Daya Manusia, PT. Logos Wacana Ilmu, Jakarta, 1999.

Prof. Dr. Mastuhu, M.Ed., Menata Ulang Pemikiran Sistem Pendidikan Nasional dalam Abad 21, Safira Insani Press, MSI UII, Yogyakarta, 2004.

Newsletter, Anti Korupsi Harus Jadi Agenda Utama Sebelum dan Sesudah Pemiu 2004, Kemitraan Bagi Pembaruan Tata Pemerintahan di Indonesia, Jakarta, Edisi II, 2004

Majalah Tengah Bulanan Suara Muhammadiyah, Membuat Koruptor Menggigil, Pers Suara Muhammadiyah, Yogyakarta, Edisi 89, 2004.

Francis Wahono, Kapitalisme Pendidikan Antara Kompetisi dan Keadilan. Insist Press, Cindelaras, Pustaka Pelajar, Yogyakarta, 2001. 